\title{
Porównanie odporności na zużycie ścierne płyt trudnościeralnych
}

\author{
Comparison of abrasion resistance of wear plates
}

\section{Streszczenie}

W artykule przedstawiono wyniki badań dotyczących porównania odporności na zużycie ścierne kilku różnych płyt trudnościeralnych produkowanych przez producentów krajowych i zagranicznych w technologiach automatycznego napawania łukowego drutem proszkowym (FCAW), ręcznego napawania łukowego elektrodami otulonymi (MMAW) oraz spajania metalurgicznego stalowej płyty podkładowej z żeliwem stopowym o wysokiej odporności na ścieranie. W oparciu o wyniki badań odporności na zużycie ścierne prowadzone zgodnie z normą ASTM G65-00 względem materiału referencyjnego stali Hardox 400 oraz pomiar twardości warstw roboczych materiałów trudnościeralnych wg PN -EN ISO 6508-1:2016, wytypowano produkty o najlepszych parametrach użytkowych do zastosowań w aplikacjach narażonych na silne zużycie ścierne typu metal-minerał.

Słowa kluczowe: ścieranie; tribologia; napawanie; FCAW; MMAW; zużycie

\begin{abstract}
In this article results of abrasive wear resistance of a few different steel wear plates made by domestic and foreign producers in technology of automatic FCAW and manual arc (MMAW) cladding and metallurgical bonding of wear resistant layer with base material were presented. Based on abrasive wear resistance tests according to ASTM G65-00, in regard to reference samples from Hardox 400 steel and hardness measurements according to PN-EN ISO 65081:2016 standard, products with best performance parameters on metal-mineral abrasion conditions were chosen.
\end{abstract}

Keywords: abrasion; tribology; cladding; FCAW; MMAW; wear

\section{Wstęp}

Opracowywanie oryginalnych składów chemicznych i technologii wytwarzania materiałów nowej generacji, które pozwalałyby na intensywne i długotrwałe użytkowanie części maszyn i urządzeń w warunkach intensywnej eksploatacji jest konieczne, szczególnie biorąc pod uwagę względy ekonomiczne [1]. Obecnie producenci oferują szeroki asortyment materiałów w postaci blach, płyt oraz rur odpornych na mechanizmy zużycia np. ścieranie, erozje, korozje, zmęczenie itp. Często różne mechanizmy zużycia są ze sobą wzajemnie powiązane, a siła ich oddziaływania zależy nie tylko od warunków środowiskowych miejsca pracy części maszyny lub urządzenia, ale także od rodzaju i parametrów obciążenia [2:9].

Z tego względu, wybór właściwego materiału konstrukcyjnego spełniającego założone kryteria użytkowe jest trudny i wymaga szczegółowej analizy, a niekiedy również modyfikacji istniejących rozwiązań zabezpieczających powierzchnie przed zużyciem. Odporność na zużycie i szczególne właściwości materiałów uzyskiwane są dzięki specjalnemu i złożonemu procesowi produkcyjnemu, co sprawia, że mogą być one stosowane między innymi w takich gałęziach przemysłu jak: energetyka, budownictwo, górnictwo i metalurgia, do produkcji części maszyn i urządzeń eksploatowanych w szczególnie trudnych warunkach pracy, np. elementów kruszarek, rozdrabniaczy i mieszadeł, czerpaków i krawędzi roboczych maszyn do robót ziemnych, ślimaków przenośników śrubowych, podajników, skipów, lei i rynien zsypowych, rurociągów przesyłowych itp.

Materiały trudnościeralne to specjalne stopy o twardości zbliżonej do diamentu, a przy tym spawalne i odporne na obciążenia udarowe. Współcześnie wytwarzane stale trudnościeralne (wysokojakościowe stale odporne na ścieranie np. Hardox, Hardstal, Miilux, HTK), dzięki wysokiej czystości metalurgicznej, wyróżniają się wysoką wytrzymałością mechaniczną, dobrą spawalnością, a także podatnością do przeróbki plastycznej i dostateczną skrawalnością. Jednakże koszty wytwarzania i zakupu tych stali nadal są wysokie.

Atrakcyjną alternatywę dla tego typu materiałów konstrukcyjnych stanowią prefabrykaty odporne na zużycie w postaci płyt trudnościeralnych wykonywane najczęściej w technologiach automatycznego napawania łukowego

Dr inż. Artur Czupryński, dr inż. Tomasz Kik - Politechnika Śląska; mgr inż. Marcin Melcer - Messer Eutectic Castolin Sp. z o.o.

Autor korespondencyjny/Corresponding author: artur.czuprynski@polsl.pl 
drutem proszkowym (FCAW), napawania plazmowego proszkowego (PPTAW), ręcznego napawania łukowego elektrodami otulonymi (MMAW) oraz metodami przetapiania proszków w piecach próżniowych lub spajania metalurgicznego płyty podkładowej z trudnościeralną warstwą roboczą z żeliwa stopowego [7].

Jako materiał podstawowy, w zależności od przeznaczenia płyty, stosuje się blachy z różnych gatunków stali, najczęściej łatwo spawalnych stali niestopowych konstrukcyjnych (np. S235 JR+N, S355 JR+N), ale także stali wysokostopowych (np. 1.4301 (316L)). Powierzchnia robocza narażona na zużycie, w zależności od środowiska i warunków pracy, jest napawana materiałami na bazie żelaza z wtrąceniami węglików $\mathrm{Cr}, \mathrm{Nb}, \mathrm{V}$ i W oraz borków, podwyższających odporność na ścieranie. Warstwę napawaną o grubości ok. $50 \div 80 \%$ materiału bazowego uzyskuje się przy użyciu wysokostopowych drutów proszkowych typu Fe-C-Cr lub proszków do napawania plazmowego gatunku Ni-Cr-Si. Poprzez odpowiedni dobór składu chemicznego i struktury warstwy wierzchniej można wydłużyć żywotność płyt trudnościeralnych, a tym samym zwiększyć efektywny czas pracy urządzeń mechanicznych. Możliwa do uzyskania odporność naścieranie, wprzypadkuzastosowanianapawanych warstw wie-rzchnich ze złożonymi fazami węglikowymi o twardości $1500 \div 3000$ HV w porównaniu z popularnymi materiałami odpornymi na ścieranie jest od kilku do nawet kilkunastu razy większa. Płyty odporne na zużycie są nowoczesnym i ekonomicznym rozwiązaniem stosowanym podczas regeneracji zużytych podzespołów maszyn, a także w produkcji nowych części charakteryzujących się wysoką odpornością na zużycie ścierne i erozję. Główną zaletą tych płyt jest możliwość regeneracji dużych zużytych powierzchni, szczególnie w przypadkach, gdy masakonstrukcjiniejest najważniejszym parametrem roboczym. Gotowe płyty trudnościeralne mogą być cięte plazmowo na różne kształty i formowane przez zginanie lub walcowanie w celu wytworzenia fragmentów wyściółki lub części maszyny. W zależności od rodzaju obciążenia, jakiemu poddawane są elementy wykonane z płyty odpornej na zużycie, mocuje się je do regenerowanych części z wykorzystaniem technologii spawania za pomocą ciągłych lub przerywanych spoin pachwinowych, klei przy użyciu kompozytów żywiczno-metalicznych, a także po uprzednim wypaleniu otworów przykręca lub nituje. Dzięki ich zastosowaniu uzyskuje się znaczące oszczędności wynikające z redukcji kosztów materiałowych oraz skrócenia czasu przerw w produkcji, potrzebnego na wymianę zużytych części na nowe [1 $\div 9]$.

\section{Przebieg badań}

\section{Materiały}

Celem badań było określenie odporności na zużycie ścierne kilku powszechnie stosowanych w przemyśle materiałów trudnościeralnych produkcji krajowej i zagranicznej. Właściwości stalowych płyt odpornych na zużycie ścierne, z warstwami wierzchnimi wykonanymi $\mathrm{w}$ procesie napawania łukowego metodami FCAW i MMAW oraz komponentu dwuwarstwowego spajanego metalurgicznie, porównano z materiałem referencyjnym w postaci stali Hardox 400 (tabl. I).

\section{Badania odporności na zużycie ścierne warstwy roboczej materiału trudnościeralnego}

Badania odporności na zużycie ścierne typu metal-minerał warstw roboczych płyt trudnościeralnych wykonanych w technologii napawania łukowego, elementu z warstwą roboczą wykonaną z żeliwa chromowo-molibdenowego (AbrecoPlate) oraz materiału referencyjnego (stali Hardox 400) przeprowadzono zgodnie z normą ASTM G 65-00, Procedura A [17]. Próbę wykonano na stanowisku badawczym przedstawionym na rysunku 1.

W celu przeprowadzenia prób ścieralności z wytypowanych materiałów trudnościeralnych wycięto po dwie próbki o wymiarach $75 \times 25 \times 10 \mathrm{~mm}$. Podczas próby koło cierne wykonało 6000 obrotów, a natężenie przepływu ścierniwa (piasku A. F. S. Testing Stand 50-70) wynosiło $335 \mathrm{~g} / \mathrm{min}$ (rys. 2).

Przed i po próbie ścieralności próbki ważono na wadze laboratoryjnej z dokładnością do 0,0001 g. Średnią gęstość stali Hardox 400, napoin płyt trudnościeralnych oraz warstwy roboczej wykonanej z chromowo-molibdenowego żeliwa białego materiału AbrecoPlate, wyznaczono przy użyciu wagi laboratoryjnej, na podstawie trzech pomiarów gęstości

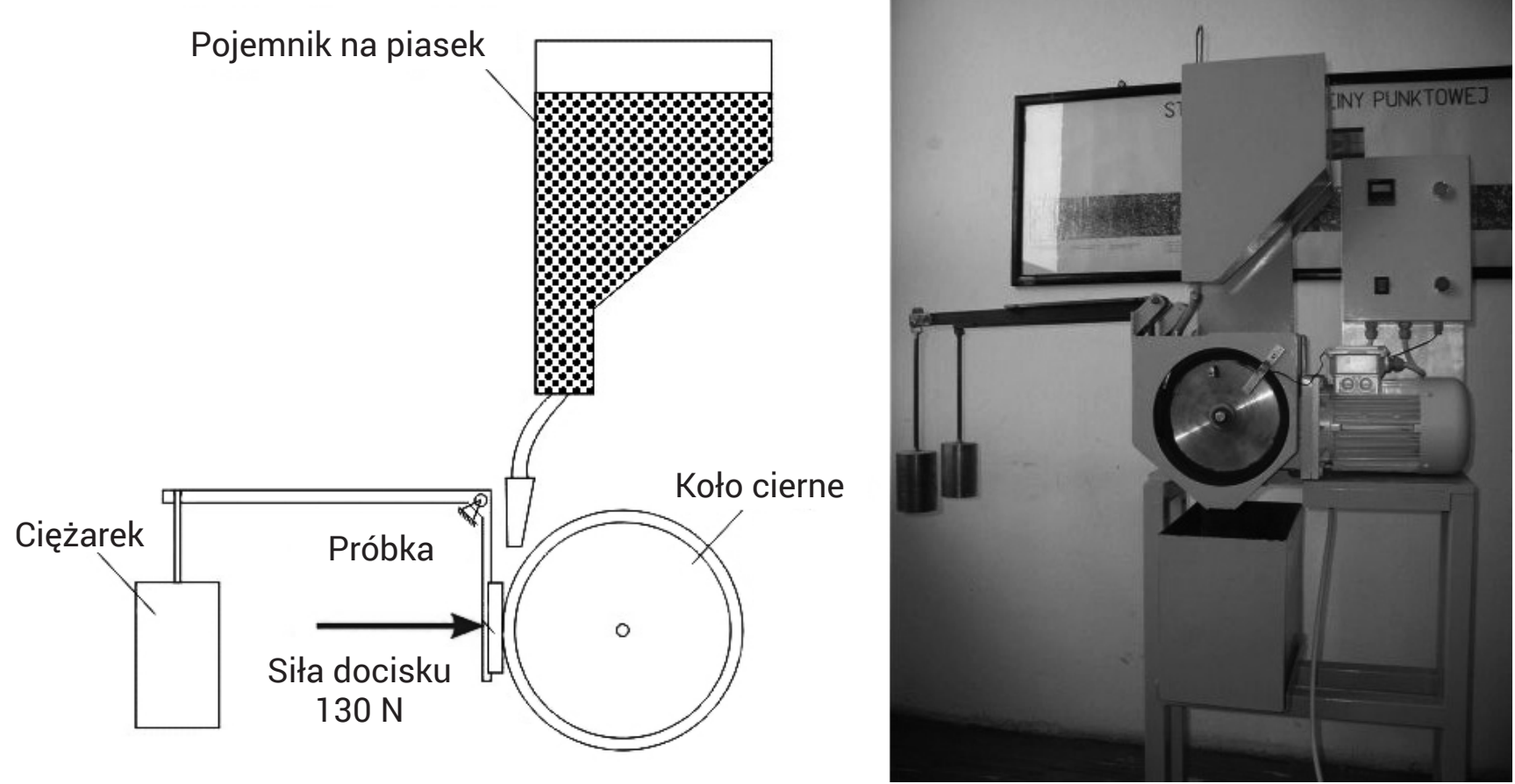

Rys. 1. Stanowisko do badań odporności na zużycie ścierne typu metal-minerał przeprowadzonych zgodnie z normą ASTM G 65-00, Procedura A Fig. 1. Metal-mineral wear resistance test stand - according to ASTM G65-00, Procedure A standard 
Tablica I. Materiały odporne na zużycie ścierne

Table I. Wear resistant materials

\begin{tabular}{|c|c|}
\hline $\begin{array}{c}\text { Producent i nazwa handlowa } \\
\text { materiału trudnościeralnego } \\
\text { (pierwiastki stopowe) } \\
\text { twardość, HRC }\end{array}$ & Opis badanego materiału \\
\hline $\begin{array}{c}\text { Contex - Alphachrom } 7000 \\
(\mathrm{C}, \mathrm{Cr}, \mathrm{Fe}) \\
64 \div 67 \mathrm{HRC}\end{array}$ & $\begin{array}{c}\text { Płyta trudnościeralna wykonana w technologii napawania łukowego drutem proszkowym z warstwą } \\
\text { roboczą o strukturze bogatej w twarde węgliki chromu równomiernie rozprowadzone w osnowie } \\
\text { żelaza a. Płyta odporna na erozje, ścieranie, uderzenia, wysoką temperaturę, korozję i działanie } \\
\text { czynników chemicznych. Nadaje się do spawania, cięcia plazmowego oraz formowania poprzez } \\
\text { walcowanie i gięcie na prasach [10] }\end{array}$ \\
\hline $\begin{array}{c}\text { CeraMetal }-\mathrm{HCNb} \\
(\mathrm{C}, \mathrm{Cr}, \mathrm{Nb}, \mathrm{Fe}) \\
60 \div 64 \mathrm{HRC}\end{array}$ & $\begin{array}{c}\text { Płyta trudnościeralna z napawaną łukowo drutem proszkowym warstwą roboczą o strukturze } \\
\text { austenitycznej z wydzieleniem węglików chromu i niobu. Stosowana w aplikacjach wymagających } \\
\text { bardzo wysokiej odporność na ścieranie, szczególnie typu metal-metal, wyższej temperatury pracy } \\
\text { oraz średniej odporności na obciążenia udarowe. Stosowana na łopaty i komponenty mieszadeł } \\
\text { oraz walcarek, a także leje, rynny zsypowe itp. Nadaje się do spawania oraz formowania poprzez } \\
\text { cięcie plazmowe, walcowanie i gięcie na prasach [11] }\end{array}$ \\
\hline $\begin{array}{c}\text { CeraMetal }-\mathrm{HCCr} \\
(\mathrm{C}, \mathrm{Cr}, \mathrm{Fe}) \\
58 \div 62 \mathrm{HRC}\end{array}$ & $\begin{array}{l}\text { Płyta trudnościeralna z napawaną łukowo drutem proszkowym warstwą roboczą o strukturze } \\
\text { austenitycznej z wydzieleniem bardzo twardych węglików chromu }\left(\mathrm{Cr}_{7} \mathrm{C}_{3}-1730 \mathrm{HV}\right) \mathrm{w} \text { stężeniu } \\
>50 \% \text {. Stosowana w środowisku pracy od którego wymaga się wysokiej odporności na ścieranie } \\
\text { oraz średniej odporności na uderzenia. Może pracować w temperaturze nawet powyżej } 500{ }^{\circ} \mathrm{C} \text {. } \\
\text { Stosowana na łopaty i części mieszadeł oraz walcarek, a także rury, zgarniarki itp. Płyta nadaje się } \\
\text { do spawania oraz formowania poprzez cięcie plazmowe, walcowanie i gięcie na prasach [11] }\end{array}$ \\
\hline $\begin{array}{c}\text { Kalenborn - Kalmetall W } 150 \text { FD } \\
(\text { C, Cr, B, W, V, Fe }) \\
65 \text { HRC }\end{array}$ & $\begin{array}{c}\text { Płyta trudnościeralna wykonana w technologii napawania łukowego drutem proszkowym z rdzeniem } \\
\text { topnikowym składającym się z: C, Cr, B, W, V tworzącym stopiwo o bardzo twardej strukturze } \\
\text { martenzytyczno-węglikowej. Warstwa robocza charakteryzuje się wysoką odporność na ścieranie } \\
\text { w temperaturze do } 350^{\circ} \mathrm{C} \text {. Może być stosowana na części maszyn i urządzeń pracujące w przemyśle } \\
\text { ceglarskim, a także do zabezpieczania ślimaków przenośników śrubowych transportujących } \\
\text { piasek i glinę [12] }\end{array}$ \\
\hline $\begin{array}{c}\text { Castolin - CDP } 4624 \\
(\mathrm{C}, \mathrm{Cr}, \mathrm{Mn}, \mathrm{Si}, \mathrm{Fe}) \\
57 \div 60 \mathrm{HRC}\end{array}$ & $\begin{array}{l}\text { Płyta trudnościeralna z napawaną łukowo warstwą roboczą o strukturze zawierającej powyżej } 30 \% \\
\text { twardych węglików chromu ( } 1800 \div 2000 \mathrm{HV}) \text {. Stosowana głównie do ochrony części maszyn } \\
\text { i urządzeń technologicznych przed ścieraniem materiałami mineralnymi oraz zabezpieczenie } \\
\text { przed zużyciem erozyjnym pyłoprzewodów, urządzeń odpylających, wentylatorów itp. Może } \\
\text { pracować w temperaturach do ok. } 250^{\circ} \mathrm{C} \text { oraz warunkach niewielkiego udaru. Nadaje się } \\
\text { do spawania, formowania poprzez cięcie plazmowe, walcowanie i gięcie na prasach [13] }\end{array}$ \\
\hline $\begin{array}{c}\text { Castolin - CDP } 4666 \\
(\mathrm{C}, \mathrm{Cr}, \mathrm{Nb}, \mathrm{B}, \mathrm{Fe}) \\
62 \div 65 \mathrm{HRC}\end{array}$ & $\begin{array}{c}\text { Płyta trudnościeralna z napawaną łukowo drutem proszkowym z warstwą roboczą zawierającą } \\
\text { powyżej } 50 \% \text { węglika chromu } \mathrm{Cr}_{7} \mathrm{C}_{3} \text { oraz dodatkowo węglik niobu } \mathrm{NbC} \text { i borek chromu } \mathrm{Cr}_{2} \mathrm{~B} \text {, } \\
\text { odznaczająca się wyjątkową odpornością na ścieranie i erozję. Obszar zastosowania podobny } \\
\text { jak w przypadku płyty CDP } 4624 \text {. Może pracować w temperaturach do ok. } 400{ }^{\circ} \mathrm{C} \text { oraz warunkach } \\
\text { niewielkiego udaru. Nadaje się do spawania oraz formowania poprzez walcowanie } \\
\text { i gięcie na prasach [13] }\end{array}$ \\
\hline $\begin{array}{c}\text { SIJ Elektrode }- \text { Abradur } 64 \\
(\mathrm{C}, \mathrm{Cr}, \mathrm{Nb}, \mathrm{Fe}) \\
62 \div 65 \mathrm{HRC}\end{array}$ & $\begin{array}{l}\text { Płyta trudnościeralna wykonana w technologii ręcznego napawania łukowego metodą MMAW } \\
\text { grubo otuloną elektrodą Abradur } 64 \text { z warstwą roboczą odporną na zużycie ścierne i umiarkowane } \\
\text { obciążenia udarowe. Warstwa napawana szczególnie zalecana do zabezpieczania ślimacznic } \\
\text { i zębów czerpaków koparek [14] }\end{array}$ \\
\hline $\begin{array}{c}\text { Castolin }- \text { EnDOTec }{ }^{\circledR} \mathrm{DO} * 390 \mathrm{~N} \\
\text { (Fe, C, Si, Mn, Cr, Mo, Nb, W, B) } \\
71 \mathrm{HRC}\end{array}$ & $\begin{array}{c}\text { Płyta trudnościeralna wykonana w technologii napawania łukowego drutem proszkowy z warstwą } \\
\text { roboczą charakteryzującą się dużymi, złożonymi i bardzo twardymi frakcjami węglików boru } \\
\text { (M23 (BC)), węglików metali (MC) i borków metali (M2 B). Węgliki i borki w skali mikronowej są } \\
\text { bardzo silnie zdyspergowane w osnowie żelaza a. Płyta wykazuje wysoką odporność } \\
\text { na zużycie ścierne i erozję oraz odznacza się umiarkowaną odpornością na udar. Może pracować } \\
\text { w temperaturze do ok. } 750^{\circ} \mathrm{C} \text { [13] }\end{array}$ \\
\hline $\begin{array}{c}\frac{\text { Canadian Wear Technologies }}{\text { Ltd. }} \\
\text { - AbrecoPlate } \\
\text { (C, Cr, Mo, Mn, Si, Ni, Fe) } \\
64 \text { HRC }\end{array}$ & $\begin{array}{c}\text { Warstwowy materiał trudnościeralny złożony z twardego i bardzo odpornego na ścieranie chromowo- } \\
\text { molibdenowego żeliwa białego, z bazą z surówki srebrzystej-krzemowej metalurgicznie spojonego } \\
\text { na całej powierzchni z płytą podkładową ze stal miękkiej, która zapewnia dobrą spawalność } \\
\text { i poprawne funkcjonowanie elementu nawet w przypadku pęknięcia warstwy żeliwnej. } \\
\text { Materiał trudnościeralny odznaczający się wysoką odpornością na ścieranie, obciążenia udarowe, } \\
\text { wilgoć i korozję [15] }\end{array}$ \\
\hline $\begin{array}{l}\frac{\text { SSAB Special Steels }}{- \text { Hardox } 400} \\
(\mathrm{C}, \mathrm{Mn}, \mathrm{Mo}, \mathrm{Cr}, \mathrm{Si}, \mathrm{Ni}, \mathrm{Fe}) \\
40 \div 46 \mathrm{HRC}\end{array}$ & $\begin{array}{l}\text { Blacha ze stali trudnościeralnej, przeznaczona do zastosowań wymagających odporność } \\
\text { na ścieranie w połączeniu z wysoką udarnością i dobrą podatnością na gięcie i spawanie. } \\
\text { Stosowana przy produkcji kruszarek, płyt sitowych, podajników, czopów, krawędzi skrawających, } \\
\text { przenośników, łyżek koparek, noży, kół zębatych, wywrotek, ładowarek, wózków przemysłowych, } \\
\text { lemieszy spychaczy, rur przesyłowych, przenośników ślimakowych itp. [16] }\end{array}$ \\
\hline
\end{tabular}




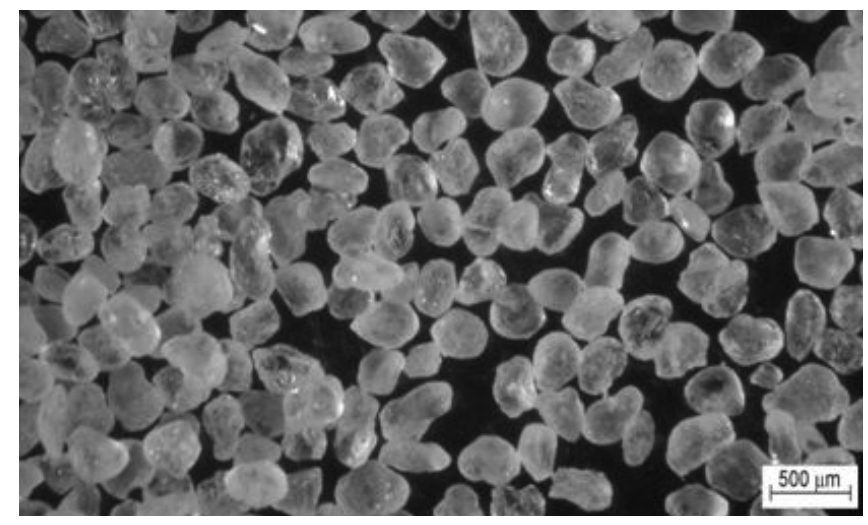

Rys. 2. Widok ziaren materiału ściernego A. F. S. Testing Sand 50-70 stosowanego $\mathrm{w}$ badaniach odporności na ścieranie przeprowadzonych zgodnie z normą ASTM G 65-00, Procedura A

Fig. 2. A view of abrasive material particles A. F. S. Testing Sand 50-70 used in ASTM G65-00, Procedure A wear resistance test próbek, pobranych z badanych materiałów, ważonych w powietrzu i cieczy (tabl. II). Wykorzystując zmierzoną średnią gęstość trudnościeralnej warstwy roboczej i średni ubytek masy próbki po próbie ścierania zgodnie ze wzorem (1) obliczono objętościowy ubytek masy:

Ubytek objętościowy masy $\left[\mathrm{mm}^{3}\right]=\frac{\text { Ubytek masy }[\mathrm{g}]}{\text { Gęstość }\left[\mathrm{g} / \mathrm{cm}^{3}\right] \text { x1000 }}$

Uzyskane w ten sposób wyniki odniesiono do odporności na zużycie ścierne stali Hardox 400 wyznaczając względną odporność na zużycie ścierne typu metal-minerał poszczególnych warstw roboczych materiałów trudnościeralnych (tabl. III).

Widok powierzchni próbek po badaniu odporności na zużycie ścierne typu metal-minerał przeprowadzonego zgodnie z normą ASTM G 65-00, Procedura A, przedstawiono na rysunku 3 .

Tablica II. Gęstość metalu warstwy roboczej odpornej na zużycie ścierne oraz stali Hardox 400

Table II. Density of wear resistant layers metal and Hardox 400 steel

\begin{tabular}{|c|c|c|c|c|}
\hline Oznaczenie próbki & $\begin{array}{c}\text { Masa próbki } \\
\text { ważonej w powietrzu [g] }\end{array}$ & $\begin{array}{c}\text { Masa próbki } \\
\text { ważonej w cieczy [g] }\end{array}$ & Gęstość [g/cm³] & Średnia gęstość $\left[\mathrm{g} / \mathrm{cm}^{3}\right]$ \\
\hline \multirow{3}{*}{ Alphachrom 7000} & 2,5030 & 2,1615 & 7,3119 & \multirow{3}{*}{7,3324} \\
\hline & 3,1960 & 2,7632 & 7,3670 & \\
\hline & 1,8231 & 1,5745 & 7,3183 & \\
\hline \multirow{3}{*}{$\mathrm{HCNb}$} & 1,4120 & 1,2204 & 7,3537 & \multirow{3}{*}{7,3559} \\
\hline & 1,2885 & 1,2192 & 7,3054 & \\
\hline & 2,3742 & 2,0545 & 7,4087 & \\
\hline \multirow{3}{*}{$\mathrm{HCCr}$} & 1,2825 & 1,1091 & 7,3807 & \multirow{3}{*}{7,3756} \\
\hline & 1,7063 & 1,4750 & 7,3614 & \\
\hline & 1,9046 & 1,6473 & 7,3846 & \\
\hline \multirow{3}{*}{ W 150 FD } & 2,0344 & 1,7638 & 7,5047 & \multirow{3}{*}{7,4643} \\
\hline & 1,1665 & 1,0103 & 7,4503 & \\
\hline & 0,7120 & 0,6165 & 7,4379 & \\
\hline \multirow{3}{*}{ CDP 4624} & 2,3466 & 2,0271 & 7,3287 & \multirow{3}{*}{7,3451} \\
\hline & 1,9783 & 1,7094 & 7,3419 & \\
\hline & 1,6484 & 1,6484 & 7,3646 & \\
\hline \multirow{3}{*}{ CDP 4666} & 1,6544 & 1,4300 & 7,3567 & \multirow{3}{*}{7,3644} \\
\hline & 1,8742 & 1,6203 & 7,3631 & \\
\hline & 1,4904 & 1,2887 & 7,3735 & \\
\hline \multirow{3}{*}{ Abradur 64} & 2,1547 & 1,8537 & 7,1450 & \multirow{3}{*}{7,1544} \\
\hline & 1,7651 & 1,5191 & 7,1622 & \\
\hline & 1,8936 & 1,6295 & 7,1561 & \\
\hline \multirow{3}{*}{$\begin{array}{l}\text { EnDOtec } \\
\text { DO*390N }\end{array}$} & 2,4378 & 2,1226 & 7,7301 & \multirow{3}{*}{7,7208} \\
\hline & 1,9345 & 1,6844 & 7,7012 & \\
\hline & 1,7961 & 1,5639 & 7,7312 & \\
\hline \multirow{3}{*}{ AbrecoPlate } & 1,8836 & 1,6360 & 7,6022 & \multirow{3}{*}{7,5961} \\
\hline & 1,4717 & 1,2783 & 7,5801 & \\
\hline & 1,2086 & 1,0498 & 7,6001 & \\
\hline \multirow{3}{*}{ Hardox 400} & 1,2876 & 1,1203 & 7,6775 & \multirow{3}{*}{7,7620} \\
\hline & 1,4927 & 1,3031 & 7,8537 & \\
\hline & 1,4863 & 1,2950 & 7,7548 & \\
\hline
\end{tabular}


Tablica III. Wyniki badań odporności na zużycie ścierne materiałów trudnościeralnych w odniesieniu do odporności na ścieranie stali Hardox 400 Table III. Results of wear resistance tests of different material in comparison with Hardox 400 steel wear resistance

\begin{tabular}{|c|c|c|c|c|c|c|c|c|}
\hline \multicolumn{9}{|c|}{ Wyniki próby ścierania } \\
\hline $\begin{array}{l}\text { Oznaczenie } \\
\text { próbki }\end{array}$ & $\begin{array}{c}\mathrm{Nr} \\
\text { próbki }\end{array}$ & $\begin{array}{c}\text { Masa } \\
\text { przed testem } \\
\text { [g] }\end{array}$ & $\begin{array}{c}\text { Masa } \\
\text { po teście } \\
{[\mathrm{g}]}\end{array}$ & $\begin{array}{l}\text { Ubytek masy } \\
\text { [g] }\end{array}$ & $\begin{array}{c}\text { Średni } \\
\text { ubytek masy } \\
\text { [g] }\end{array}$ & $\begin{array}{c}\text { Gęstość } \\
\text { warstwy } \\
{\left[\mathrm{g} / \mathrm{cm}^{3}\right]}\end{array}$ & $\begin{array}{c}\text { Ubytek } \\
\text { objętościowy } \\
{\left[\mathrm{mm}^{3}\right]}\end{array}$ & $\begin{array}{c}\text { Względna } \\
\text { odporność } \\
\text { na ścieranie }\end{array}$ \\
\hline \multirow{2}{*}{ Hardox 400} & p01 & 62,2260 & 60,7526 & 1,4734 & \multirow{2}{*}{1,4744} & \multirow{2}{*}{7,7620} & \multirow{2}{*}{189,9510} & \multirow{2}{*}{1,00} \\
\hline & p02 & 60,7526 & 59,2773 & 1,4753 & & & & \\
\hline \multirow{2}{*}{$\begin{array}{c}\text { Alphachrom } \\
7000\end{array}$} & p01 & 157,5045 & 157,2509 & 0,2536 & \multirow{2}{*}{0,2428} & \multirow{2}{*}{7,3324} & \multirow{2}{*}{33,1133} & \multirow{2}{*}{5,74} \\
\hline & p02 & 157,0426 & 156,8107 & 0,2319 & & & & \\
\hline \multirow{2}{*}{$\mathrm{HCNb}$} & p01 & 174,3838 & 174,1851 & 0,1987 & \multirow{2}{*}{0,1981} & \multirow{2}{*}{7,3559} & \multirow{2}{*}{26,9376} & \multirow{2}{*}{7,05} \\
\hline & p02 & 176,8729 & 176,6753 & 0,1976 & & & & \\
\hline \multirow{2}{*}{$\mathrm{HCCr}$} & p01 & 160,5386 & 160,3285 & 0,2101 & \multirow{2}{*}{0,1977} & \multirow{2}{*}{7,3756} & \multirow{2}{*}{26,7978} & \multirow{2}{*}{7,09} \\
\hline & p02 & 172,0538 & 171,8686 & 0,1852 & & & & \\
\hline \multirow{2}{*}{ W 150 FD } & p01 & 87,1791 & 86,8916 & 0,2875 & \multirow{2}{*}{0,4041} & \multirow{2}{*}{7,4643} & \multirow{2}{*}{54,1377} & \multirow{2}{*}{3,51} \\
\hline & p02 & 91,8884 & 91,3677 & 0,5207 & & & & \\
\hline \multirow{2}{*}{ CDP 4624} & p01 & 134,0617 & 133,8487 & 0,2130 & \multirow{2}{*}{0,2166} & \multirow{2}{*}{7,3451} & \multirow{2}{*}{29,4890} & \multirow{2}{*}{6,44} \\
\hline & p02 & 134,2440 & 134,0238 & 0,2202 & & & & \\
\hline \multirow{2}{*}{ CDP 4666} & p01 & 161,9005 & 161,7025 & 0,1980 & \multirow{2}{*}{0,1862} & \multirow{2}{*}{7,3644} & & \\
\hline & p02 & 164,5962 & 164,4219 & 0,1743 & & & 20,2109 & 1,01 \\
\hline & p01 & 136,2893 & 136,0933 & 0,1960 & & & & \\
\hline Abradur b4 & p02 & 139,6675 & 139,4670 & 0,2005 & 0,1983 & l, 1544 & 21,1102 & b,86 \\
\hline EnDOtec $^{\circledast}$ & p01 & 155,4632 & 155,3631 & 0,1001 & & & & \\
\hline$D O * 390 N^{1)}$ & p02 & 155,8611 & 155,7620 & 0,0991 & 0,0996 & 7,7208 & 12,9000 & 14,73 \\
\hline & p01 & 173,7335 & 173,6133 & 0,1202 & & & & \\
\hline AbrecoPlate & p02 & 173,6714 & 173,5589 & 0,1125 & 0,11635 & 7,5961 & 15,3170 & 12,40 \\
\hline
\end{tabular}

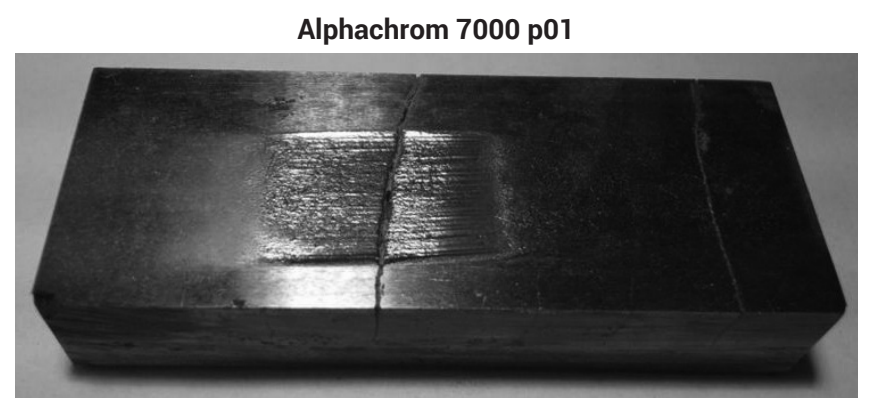

HCNb p01

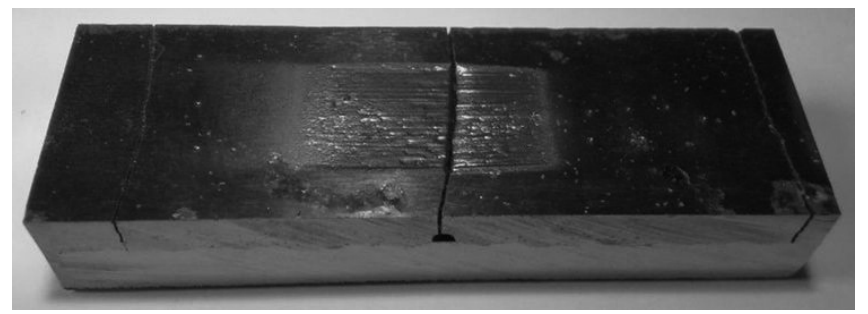

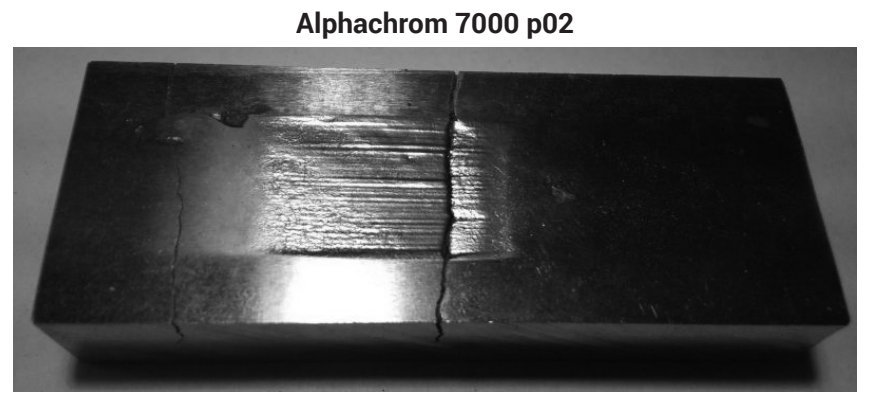

$\mathrm{HCNb}$ p02

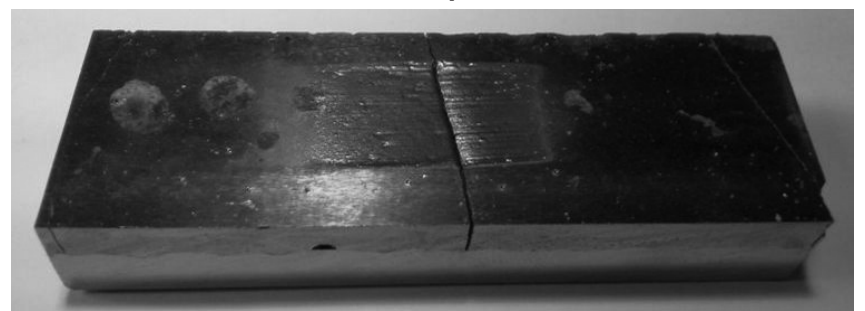

Rys. 3. Widok powierzchni próbek po badaniu odporności na zużycie ścierne typu metal-minerał wykonanego wg normy ASTM G 65-00, Procedura A

Fig. 3. A view of the surfaces of different specimens after ASTM G65-00, Procedure A metal-mineral wear resistance tests standards 
HCCr p01

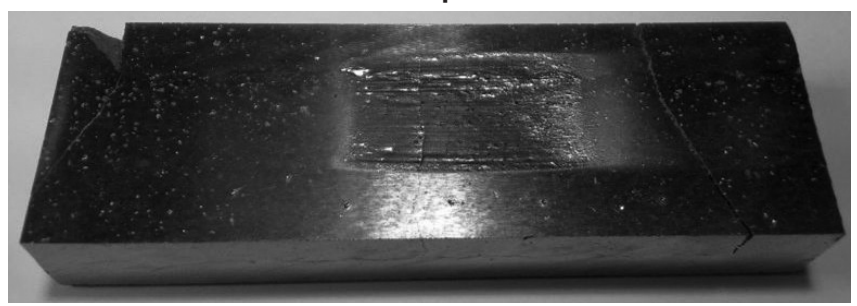

W 150 FD p01

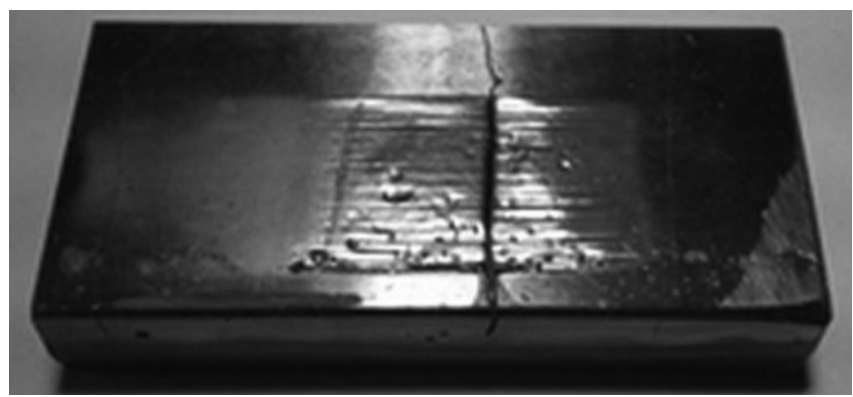

CDP 4624 p01

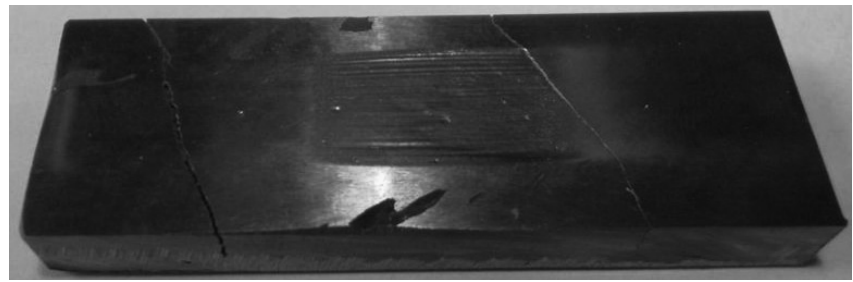

CDP 4666 p01



Abradur 64 p01

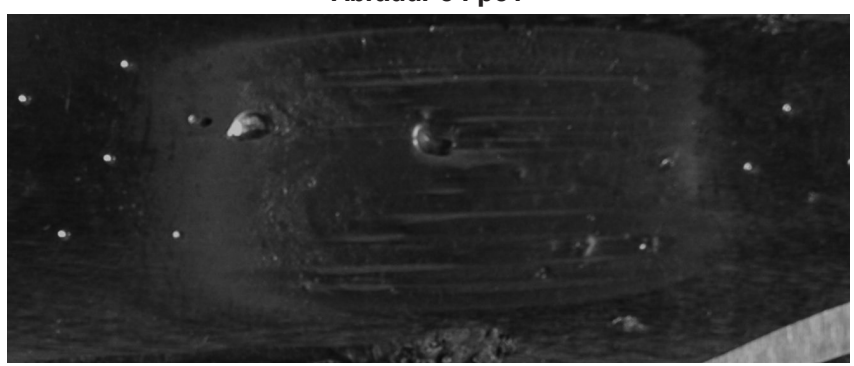

AbrecoPlate p01

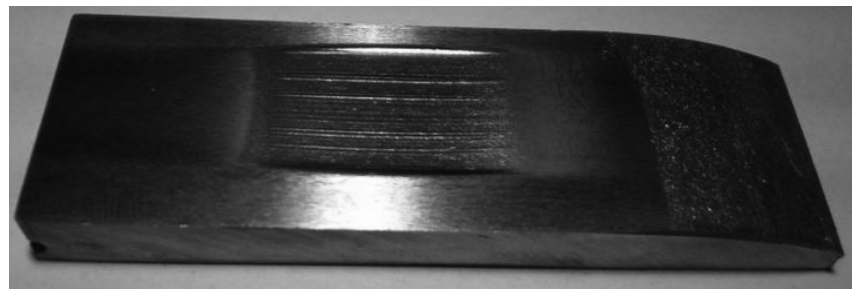

Hardox 400 p01

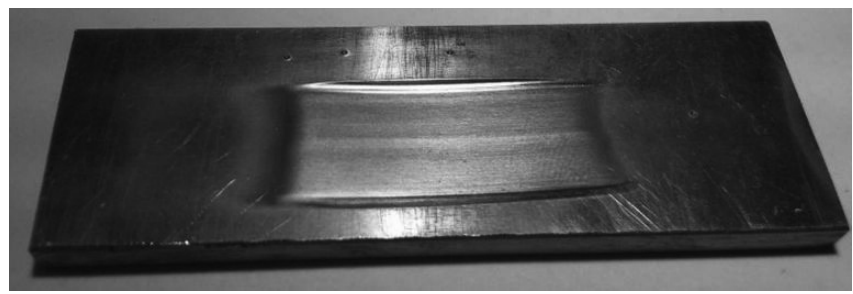

HCCr p02

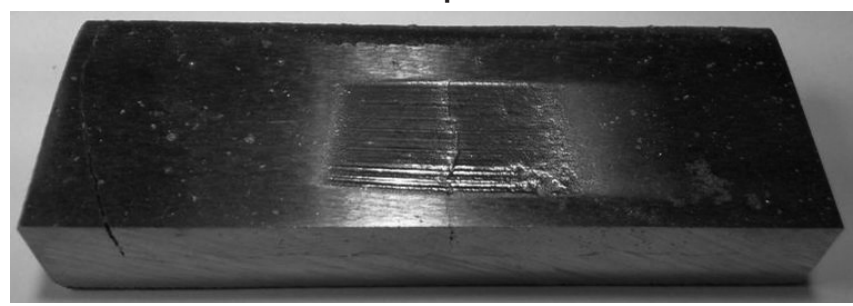

W 150 FD p02

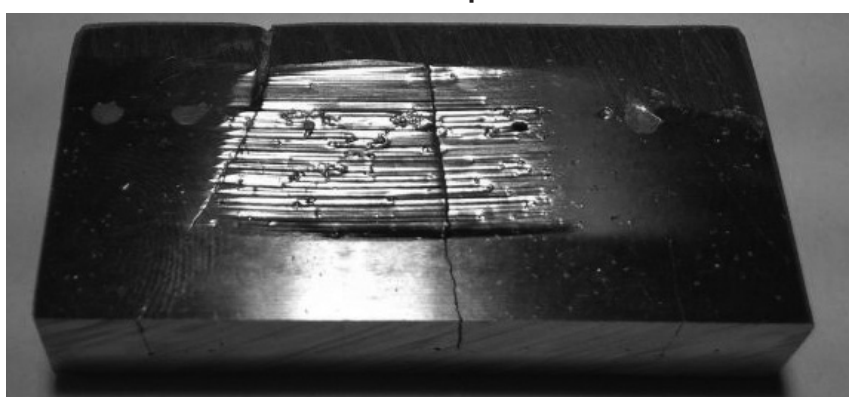

CDP 4624 p02

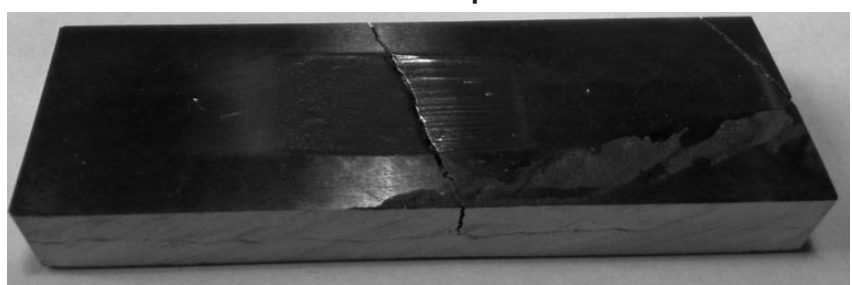

CDP 4666 p02

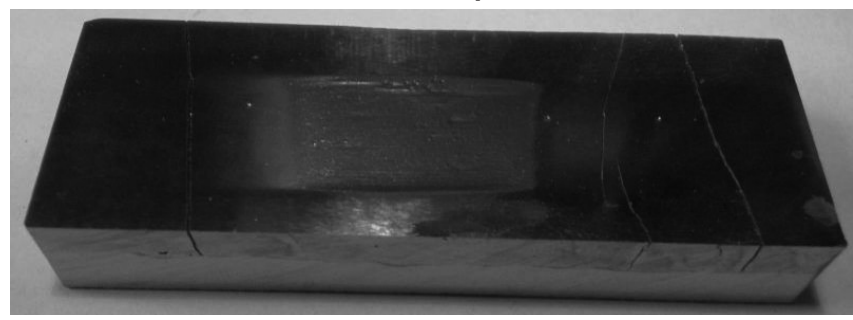

DO*390N p01

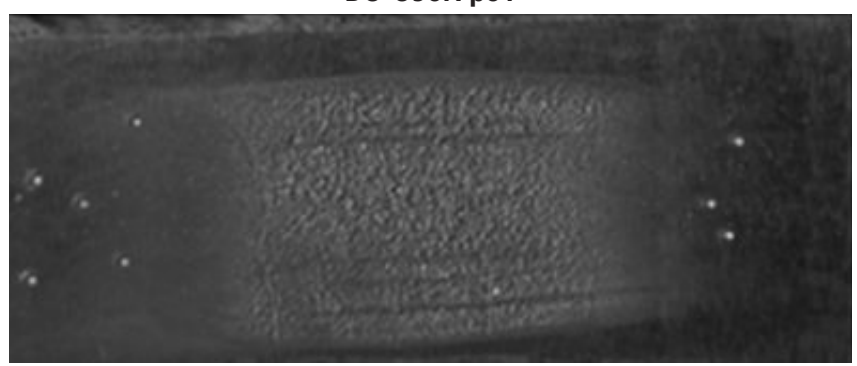

AbrecoPlate p02

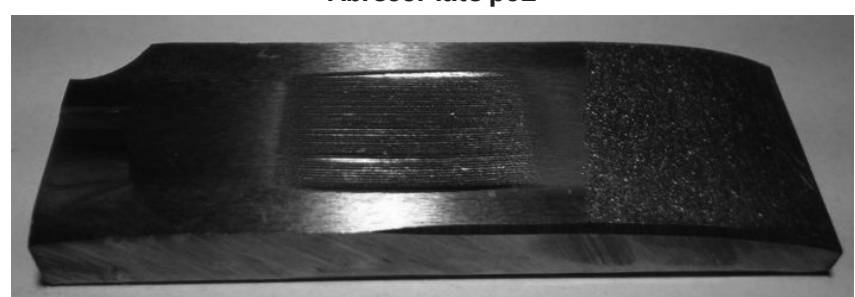

Hardox 400 p02

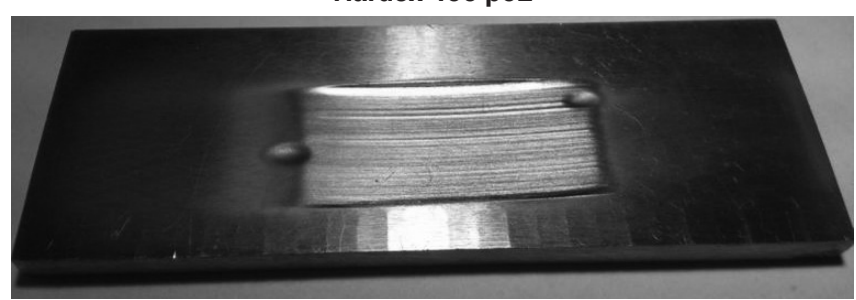

CD. Rys. 3. Widok powierzchni próbek po badaniu odporności na zużycie ścierne typu metal-minerał wykonanego wg normy ASTM G 65-00, Procedura A

Cont. Fig. 3. A view of the surfaces of different specimens after ASTM G65-00, Procedure A metal-mineral wear resistance tests standards 


\section{Pomiary twardości}

warstwy roboczej materiału trudnościeralnego

przeprowadzone sposobem Rockwella

Pomiaru twardości warstwy roboczej materiału trudnościeralnego oraz materiału referencyjnego $\mathrm{w}$ postaci stali Hardox 400 przeprowadzono sposobem Rockwella na przeszlifowanej powierzchni próbki. Badanie przeprowadzono zgodnie z normą PN-EN ISO 6508-1:2016-10 [18]. Wykonano po pięć pomiarów wzdłuż jednej linii pomiarowej umiejscowionej poza obszarem wytarcia próbki (rys. 4). Wyniki pomiarów przedstawiono $w$ tablicy IV.

\section{Badania metalograficzne}

Badanie metalograficzne mikroskopowe pozwoliło na określenie struktury warstwy roboczej badanych materiałów trudnościeralnych. Rysunek 5 przedstawia mikrostruktury materiatu odniesienia (stali Hardox 400) oraz trzech warstw roboczych płyt trudnościeralnych o najlepszej względnej odporności na ścieranie.

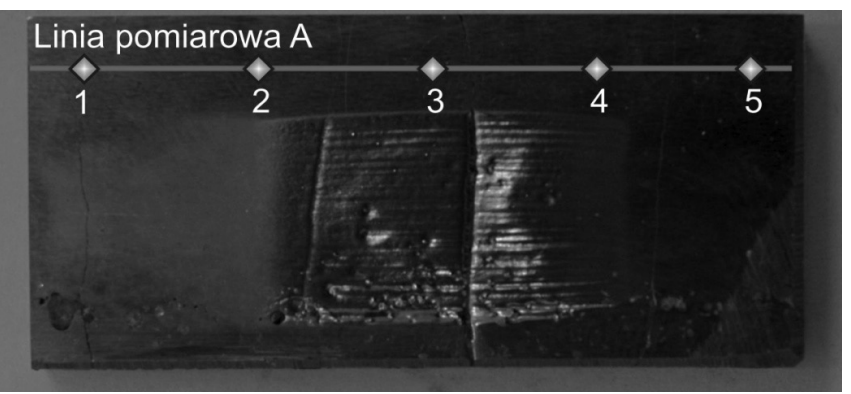

Rys. 4. Przykład rozmieszczenia punktów pomiarowych na powierzchni próbki warstwy roboczej materiału trudnościeralnego

Fig. 4. An example of measurement points on the wear resistant layer surface

Tablica IV. Wyniki pomiarów twardości warstwy roboczej materiału trudnościeralnego przeprowadzone sposobem Rockwella Table IV. Results of Rockwell hardness measurement of a wear resistant layer

\begin{tabular}{|c|c|c|c|c|c|c|c|c|}
\hline \multicolumn{9}{|c|}{ Twardość warstwy trudnościeralnej, [HRC] } \\
\hline \multirow{2}{*}{\multicolumn{2}{|c|}{ Oznaczenie i numer próbki }} & \multicolumn{7}{|c|}{ Nr punktu pomiarowego } \\
\hline & & 1 & 2 & 3 & 4 & 5 & Wart & dnia \\
\hline \multirow{2}{*}{ Alphachrom 7000} & p01 & 63,9 & 64,4 & 63,3 & 64,2 & 65,1 & 64,2 & \multirow{2}{*}{63,9} \\
\hline & p02 & 65,4 & 63,2 & 64,8 & 62,3 & 62,8 & 63,7 & \\
\hline \multirow{2}{*}{$\mathrm{HCNb}$} & p01 & 62,9 & 62,1 & 61,1 & 63,5 & 62,0 & 62,3 & \multirow{2}{*}{62,7} \\
\hline & p02 & 62,3 & 61,0 & 67,4 & 62,3 & 62,7 & 63,1 & \\
\hline \multirow{2}{*}{$\mathrm{HCCr}$} & p01 & 60,7 & 60,1 & 60,2 & 60,3 & 60,7 & 60,4 & \multirow{2}{*}{60,3} \\
\hline & p02 & 60,8 & 59,8 & 60,7 & 59,9 & 59,7 & 60,2 & \\
\hline \multirow{2}{*}{ W 150 FD } & p01 & 61,5 & 61,8 & 62,4 & 61,8 & 63,3 & 62,2 & \multirow{2}{*}{62,8} \\
\hline & p02 & 62,8 & 64,2 & 64,5 & 63,0 & 62,5 & 63,4 & \\
\hline \multirow{2}{*}{ CDP 4624} & p01 & 60,3 & 59,0 & 58,4 & 60,9 & 61,0 & 59,9 & \multirow{2}{*}{59,4} \\
\hline & p02 & 58,9 & 60,2 & 57,9 & 59,0 & 58,2 & 58,8 & \\
\hline \multirow{2}{*}{ CDP 4666} & p01 & 62,8 & 63,9 & 60,9 & 61,2 & 60,3 & 61,8 & \multirow{2}{*}{62,1} \\
\hline & p02 & 62,8 & 61,6 & 61,1 & 62,1 & 64,5 & 62,4 & \\
\hline \multirow{2}{*}{ Abradur $64^{1)}$} & p01 & 63,8 & 61,4 & 60,3 & 62,2 & 59,8 & 61,5 & \multirow{2}{*}{61,6} \\
\hline & p02 & 61,4 & 61,2 & 61,8 & 62,3 & 61,8 & 61,7 & \\
\hline \multirow{2}{*}{ EnDOtec $^{\circledR} \mathrm{DO} * 390 \mathrm{~N}^{1)}$} & p01 & 68,9 & 71,4 & 72,4 & 70,0 & 70,9 & 70,7 & \multirow{2}{*}{71,2} \\
\hline & p02 & 70,8 & 71,2 & 71,8 & 72,1 & 72,5 & 71,7 & \\
\hline \multirow{2}{*}{ AbrecoPlate } & p01 & 60,2 & 57,8 & 61,0 & 60,7 & 62,3 & 60,2 & \multirow{2}{*}{60,1} \\
\hline & p02 & 58,5 & 61,7 & 62,1 & 57,2 & 60,6 & 60,0 & \\
\hline \multirow{2}{*}{ Hardox 400} & p01 & 39,9 & 42,6 & 43,1 & 42,1 & 42,4 & 42,0 & \multirow{2}{*}{42,0} \\
\hline & p02 & 42,1 & 40,9 & 41,9 & 42,0 & 42,8 & 41,9 & \\
\hline
\end{tabular}



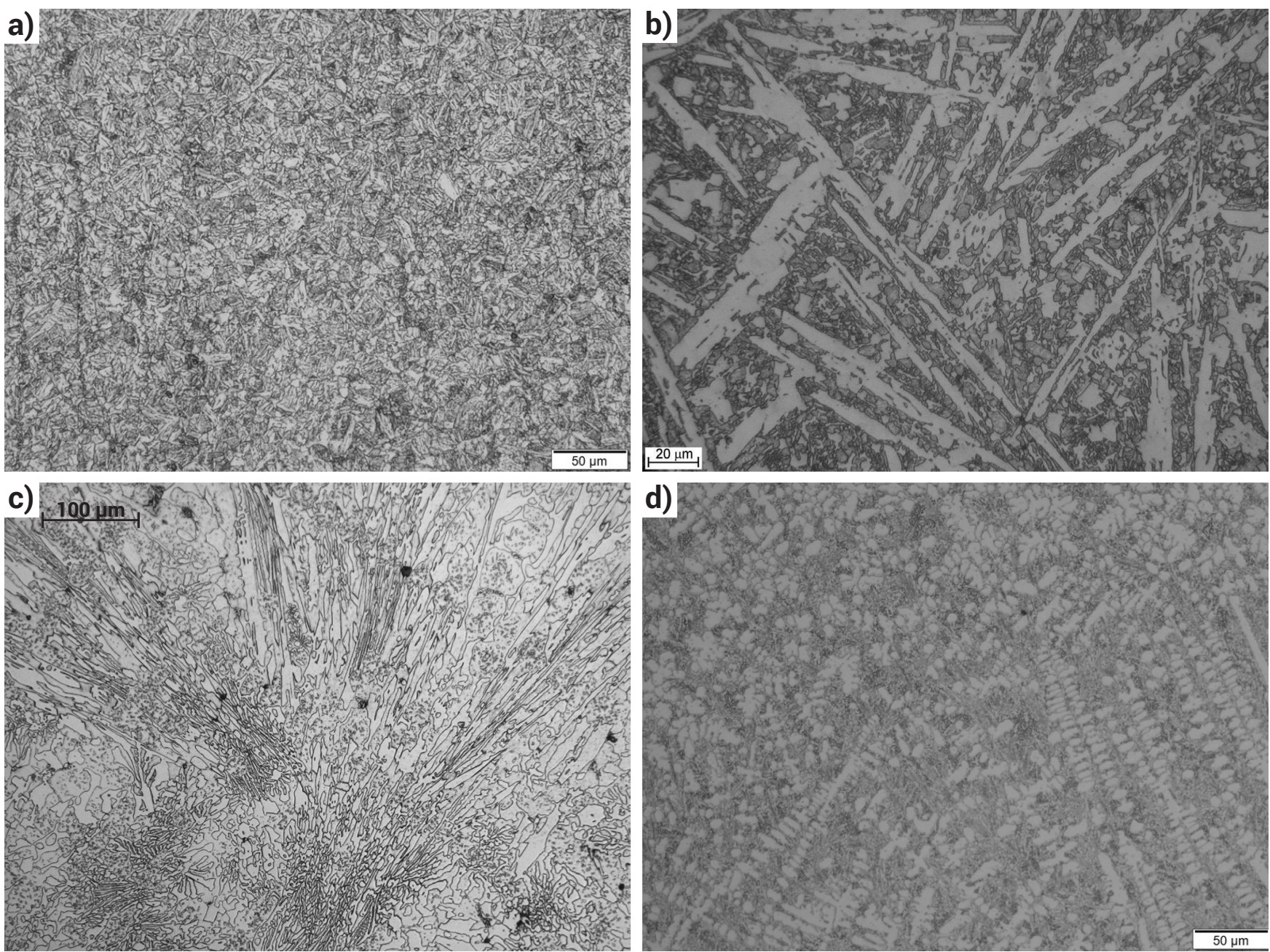

Rys. 5. Mikrostruktury: a) materiału odniesienia - stali Hardox 400; b) trudnościeralnej warstwy roboczej napawanej łukowo metodą FCAW -G drutem EnDOtec ${ }^{\circledR} \mathrm{DO} * 390 \mathrm{~N} ; \mathrm{c}$ ) warstwy roboczej materiału trudnościeralnego AbrecoPlate; d) warstwy roboczej płyty trudnościeralnej CDP 4666 wykonanej w technologii napawania łukowego metodą FCAW-S

Fig. 5. Microstructures: a) reference material - Hardox 400 steel; b) wear resistant layer FCAW-G welded with EnDOtec $\circledast$ DO $390 N$ cored wire; c) wear resistant material AbrecoPlate; d) CDP 4666 wear resistant plate FCAW-S welded

\section{Podsumowanie}

Najwyższą względną odpornością na zużycie ścierne typu metal-minerał charakteryzowała się napoina trójwarstwowa wykonana metodą FCAW-G na płycie bazowej ze stali niestopowej konstrukcyjnej, drutem proszkowym EnDOtec ${ }^{\circledR}$ DO $390 \mathrm{~N}$ dającym stopiwo bezżużlowe o wyjątkowej nano-strukturze, zawierającej jednolicie rozmieszczone w osnowie żelaza a węgliki boru, rys. 5b), która była prawie 15-krotnie bardziej odporna na zużycie ścierne niż stal Hardox 400 (rys. 6). Równie wysoką odpornością na ten typ zużycia w odniesieniu do stali Hardox 400 odznaczało się tworzywo warstwowe, złożone z chromowo-molibdenowego żeliwa białego silnie spojonego metalurgicznie z płytą podkładową ze stali niestopowej o nazwie handlowej AbrecoPlate. Względna odporność na ścieranie warstwy roboczej tego materiału nieco ponad 12-krotnie przewyższała odporność na ścieranie stali Hardox 400 (rys. 6). Względnie wysoką odpornością na zużycie ścierne wyróżniały się warstwy robocze płyt trudnościeralnych CDP 4666, HCCr i HCNb, które były ok. 7 razy bardziej odporne na ścieranie od stali Hardox 400. Najniższą odpornością na zużycie ścierne określane zgodnie z normą ASTM G 65-00, odznaczała się warstwa wierzchnia płyty trudnościeralnej W150 FD, która tylko ok. 3,5-krotnie przewyższała odpornością na zużycie materiał odniesienia.

Obok wysokiej odporności na ścieranie napoina dwuwarstwowa wykonana metodą FCAW-G drutem proszkowym EnDOtec ${ }^{\circledR}$ DO*390N wykazywała także najwyższą twardość wynoszącą ok. 71 HRC (rys. 7). Jednak nie zawsze wysoka twardość warstwy roboczej materiału trudnościeralnego przekładała się na wysoką odporność na zużycie ścierne typu metal-minerał. Pomimo wysokiej średniej twardości warstw roboczych płyt trudnościeralnych o nazwach handlowych Alphachrom 7000 (63,9 HRC) i W 150 FD (62,8 HRC) odznaczały się one względem stali Hardox 400 najniższą odpornością na zużycie ścierne. Podobnie jak w przypadku materiału trudnościeralnego AbrecoPlate, gdzie w porównaniu z innymi przebadanymi materiałami dość niska twardość warstwy roboczej (60,1 HRC) nie wpłynęła na obniżenie jego odporności na zużycie ścierne (rys. 6). Należy więc sądzić, że twardość materiału trudnościeralnego nie jest jedynym czynnikiem wpływającym na jego zużycie. 


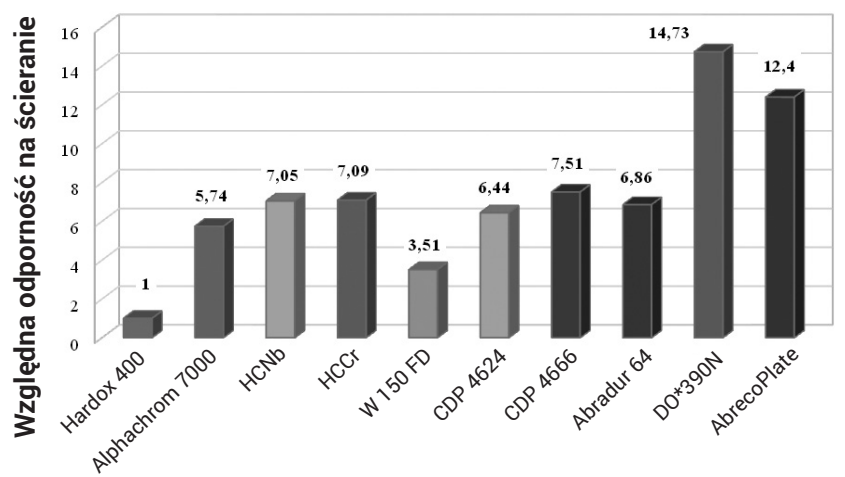

Nazwa materiału trudnościeralnego

Rys. 6. Odporność na zużycie ścierne typu metal-minerał, określana zgodnie z normą ASTM G 65-00 w odniesieniu do odporności stali Hardox 400, różnych materiałów trudnościeralnych

Fig. 6. Metal mineral wear resistance according to ASTM G65-00 standards of different materials in comparison with Hardox 400 steel

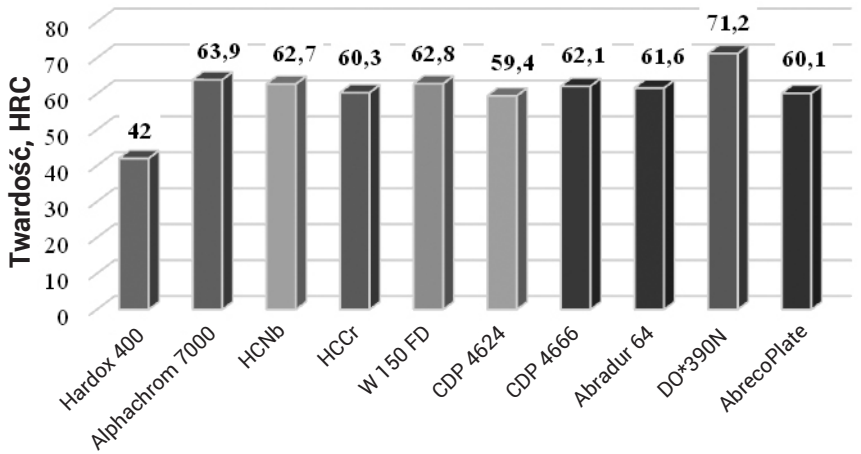

Nazwa materiału trudnościeralnego

Rys. 7. Średnia twardość, określana zgodnie z normą PN-EN ISO 6508-1:2016, powierzchni warstw roboczych materiałów trudnościeralnych

Fig. 7. Average hardness of different wear resistance materials according to PN-EN ISO 6508-1:2016 standard

\section{Literatura}

[1] Kato K.: Abrasive wear of metals, Tribology International, 1997, nr 5, pp. 333-338.

[2] Stachowiak G.W.: Particle angularity and its relationship to abrasive and erosive wear, Wear, 2000, nr 241, pp. 214-219.

[3] Zum Gahr K.H.: Wear by hard particles. Tribology International, 1998, nr 10, pp. 587-596.

[4] Gawrysiuk W.: Płyty trudnościeralne. Technologie wytwarzania i walory eksploatacyjne, Matriały seminaryjne Instytutu Spawalnictwa w Gliwicach

[5] Stachowiak G.B., Stachowiak G.W.: The effects of particle characteristics on three-body abrasive wear, Wear, 2001, nr 249, pp. 201-207.

[6] Ma X., Liu R., Li D.Y.: Abrasive wear behavior of D2 tool steel with respect to load and sliding speed under dry sand/rubber wheel abrasion condition, Wear, 2000, nr 1, pp. 79-85.

[7] Adamiec P., Gawrysiuk W.: Właściwości warstw napawanych o strukturze żeliw chromowych, Biuletyn Spawalnictwa, Gliwice 2004, nr 2.

[8] Klimpel A., Kik T.: Erosion and abrasion wear resistance of GMA wire surfaced nanostructural deposits, Journal of Archives of Materials Science and Engineering 30(2), April 2008, pp. 121-124

[9] Adamiak M., Górka J., Kik T.: Comparison of abrasion resistance of selected constructional materials, Journal of Archives of Materials Science and Engineering 37(2), December 2009, pp. 375-380.

[10] Materiały reklamowe firmy Contex.

[11] Materiały reklamowe firmy CeraMetal.

[12] Materiały reklamowe firmy Kalenborn.

[13] Materiały reklamowe firmy Castolin.

[14] Materiały reklamowe firmy SIJ Elektrode.

[15] Materiały reklamowe firmy Canadian Wear Technologies Ltd.

[16] Materiały reklamowe firmy SSAB Special Steels.

[17] ASTM G65-00: Standard Test Method for Measuring Abrasion Using the Dry Sand/Rubber Wheel Apparatus.

[18] Metale - Pomiar twardości sposobem Rockwella - Część 1: Metoda badania. 